\title{
杭基礎の間接ヘルスモニタリングのための実験的検証 EXPERIMENTAL VERIFICATION FOR INDIRECT HEALTH MONITORING OF PILE FOUNDATIONS
}

\author{
濱本卓司*，崔 井 圭**，清水睦男*** \\ Takuji HAMAMOTO, Jeongkyu CHOI and Mutsuo SHIMIZU
}

\begin{abstract}
For the purpose of detecting the global damage of pile foundations of building structure after earthquake events, an indirect health monitoring method has been developed. Acceleration sensors are located on the roof and base of superstructure and on the soil layer that supports piles. Any sensors are not installed in and on piles directly. Two simplified mathematical models, 2-lumped mass model and sway-rocking (SR) model, of superstructure-pile-soil coupled system are used to separate physical parameters of superstructure and substructure. A multi-step system identification scheme is used to estimate the change in pile stiffness before and after a damage event. A series of shaking table tests have been carried out for a small-scaled experimental model of superstructure-pile-soil coupled system. Using response data of the experiments, the effectiveness and limitations of the indirect health monitoring of pile foundations are discussed.
\end{abstract}

\section{Keywords : Indirect health monitoring, Pile foundation, Multi-step system identification, Seismic damage, Superstructure-pile-soil coupled system, Experimental verification 間接ヘルスモニタリング, 杭基礎, 多段階システム同定, 地震損傷, 上部構造 - 杭 - 地盤連成系, 実験的検証}

\section{1. 序}

軟弱な地盤上の建築物には場所打ち杭あるいは既成杭がよく用い られる。場所打ち杭の状態は，地中で打設されるため初期段階でさ え正確に把握することは難しい。既成杭の状態は，打設前は把握で きても，打設後の損傷による変化を推定することは容易ではない ${ }^{1)}$ 。 竣工後に杭の損傷を直接目視する方法は掘削以外にはないが，これ には多大のコストと時間が必要になる。また，過度の掘削は構造安 定性を損なうことにもなりかねない。地盤の掘削を最小化するため に，異種のセンサを総合的に導入する方法 ${ }^{2,3)}$ も考えられるが，本 研究では，建築物直下の地盤を掘削することなく，振動センサを上 部構造に設置して杭の損傷状態を推定する方法を提案する。

施工時，上部構造が立ち上がる段階では，すでに杭頭は基礎版に 覆われ，杭側面は地盤に取り卷かれている。竣工後の杭の状態を掘 削せずに調べる方法として，これまで，施工段階で杭にセンサを直 接取り付けておくか, 上部構造の静的特性の変化から地中の杭の状 態を推定する方法が用いられてきた。前者を直接へルスモニタリン グ，後者を間接へルスモニタリングと呼ぶことができる。直接へル スモニタリングには，従来から杭表面にひずみゲージを貼り付ける 方法 ${ }^{4}$ があり, 最近では光ファイバー5)や炭素繊維(6) などを埋め込ん だヘルスモニタリング技術の開発も行われているが，ともに新築建 物にしか適用できないという制限がある。一方，間接へルスモニ夕 リングとしては，既存建物の傾斜角や沈下量の計測が実施されてい
るが，杭の掘削調査を実施すべきかどうかの判断材料とはなるもの の，それだけで損傷状態を推定することは難しい。

掘削することなく杭の損傷を推定するもう一つの方法として, 上 部構造の動的特性の変化に着目する方法がある。大場・濱川 は上 $^{7)}$ 部構造の常時微動を計測し, 固有振動数の変化から杭の損傷状態を 推定している。しかし, 上部構造で計測された固有振動数の変化た けでは，上部構造と基礎構造の損傷を分離することはできず，杭の 損傷か上部構造の損傷かを判別することは難しい。 Luco ${ }^{8}$ は屋上に 加振機を設置して強制振動実験を行い, 地盤一構造物相互作用の影

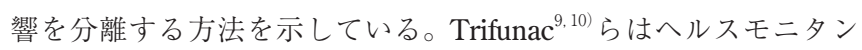
グの際に地盤一構造物相互作用を考慮することの重要性を指摘して いる。 $\operatorname{Safak}^{11)}$ は2 質点系モデルを用いてモード特性の変化から地 盤一構造物相互作用の影響を検出するシステム同定手法を示してい る。Stewart ら ${ }^{12-14)}$ はスウエイ・ロッキング $(\mathrm{SR})$ モデルを用いてモー ド特性の変化から地盤一構造物相互作用の影響を検出するシステム 同定手法を示している。しかし，上部構造および基礎構造の損傷検 出を行うには, 相互作用に伴う振動特性の変化をさらに剛性などの 物理パラメターの変化に変換する必要がある。原口ら ${ }^{15}$ は, 上部構 造の常時微動を計測し, SR モデルにおける地盤ばねの剛性と減衰 を段階的に推定している。

本研究では, 間接ヘルスモニタリングとして, 地盤一杭系（基礎 版を含む)を 1 質点系, 上部構造を 1 質点系にそれぞれ集約してロッ
* 東京都市大学工学部建築学科 教授. 工博

** 東京都市大学 大学院生.工修

*** 構造品質保証研究所(株) 工修 (元 武蔵工業大学(現 東京都市大学) 大学院生)
Prof., Dept. of Architecture, Faculty of Engineering, Tokyo City University, Dr. Eng. Graduate Student, Tokyo City University, M. Eng.

Structural Quality Assurance, Inc., M. Eng. 


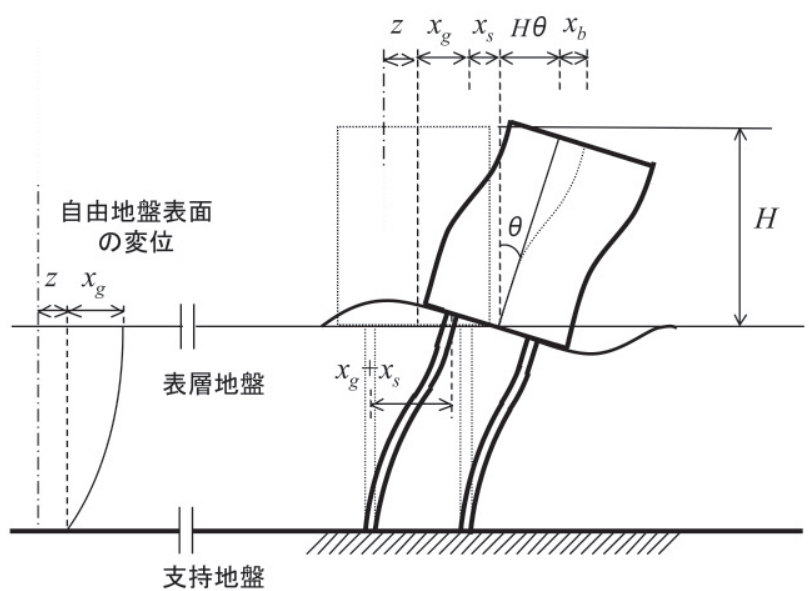

図 1 上部構造 - 杭 - 地盤連成系の変形図

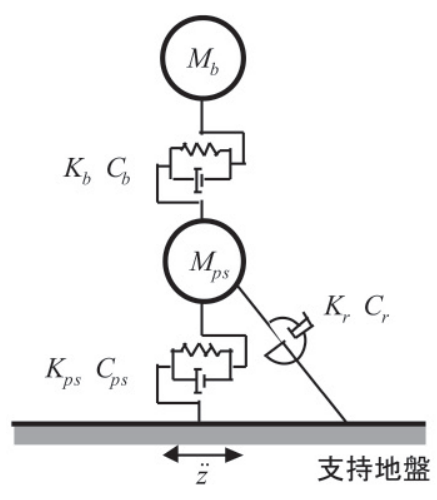

(a) 2 質点系モデル

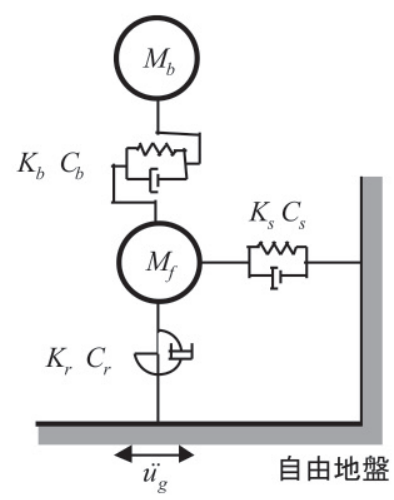

(b) SR モデル

図2 上部構造 - 杭 - 地盤連成系の数学モデル

る上部構造頂部と基礎版の相対変位, $M_{b}$ と $M_{p s}$ はそれぞれ上部構 造の質量と杭 - 地盤系の有効質量, $I$ は基礎版の回転慣性, $K_{b}$, $K_{p s}, K_{r}$ はそれぞれ上部構造, 杭一地盤系, およびロッキングばねの 剛性, $C_{b}, C_{p s}, C_{r}$ は上部構造, 杭一地盤系, およびロッキングば ねの減衰係数, ・は時間微分, $\ddot{z}$ は支持地盤表面での入力加速度で ある。なお，上部構造の回転慣性は無視している。

\subsection{SR モデル}

上部構造－杭－地盤連成系のSR モデルを図 2 (b)に示す。1 質点 系に集約した上部構造をスウェイばねとロッキングばねを有する基 礎版に結合したモデルである。SR モデルは, 通常, 上部構造の応 答挙動を再現するために用いられ，杭の変形を直接評価することは できない。スウェイばねは自由地盤と基礎版の水平変位の差を表現 するための軸ばね，ロッキングばねは自由地盤と基礎版の回転の差 を表現するための回転ばねである。杭の損傷は, スウェイばねと ロッキングばねの剛性変化に着目して検出する。入力は自由地盤表 面の水平動とし, 回転入力は考慮しない。このとき, 運動方程式は 次式のようになる。

$$
\begin{aligned}
& {\left[\begin{array}{ccr}
M_{b} & 0 & 0 \\
0 & M_{f}+M_{e g} & 0 \\
0 & 0 & I
\end{array}\right]\left\{\begin{array}{l}
\ddot{x}_{t f} \\
\ddot{x}_{s} \\
\ddot{\theta}
\end{array}\right\}+\left[\begin{array}{ccc}
C_{b} & -C_{b} & -C_{b} H \\
-C_{b} & C_{b}+C_{s} & C_{b} H \\
-C_{b} H & C_{b} H & C_{r}+C_{b} H^{2}
\end{array}\right]\left\{\begin{array}{c}
\dot{x}_{t f} \\
\dot{x}_{s} \\
\dot{\theta}
\end{array}\right\}} \\
& +\left[\begin{array}{ccc}
K_{b} & -K_{b} & -K_{b} H \\
-K_{b} & K_{b}+K_{s} & K_{b} H \\
-K_{b} H & K_{b} H & K_{r}+K_{b} H^{2}
\end{array}\right]\left\{\begin{array}{c}
x_{t f} \\
x_{s} \\
\theta
\end{array}\right\}=\left\{\begin{array}{c}
-M_{b} \ddot{u}_{g} \\
-M_{f} \ddot{u}_{g} \\
0
\end{array}\right\}
\end{aligned}
$$

もに 1 質点系に集約した上部構造と杭一地盤系（基礎版を含む）を 直列に繋ぎ，基礎版と支持地盤の間をロッキングばねで結合したモ デルである。2 質点系モデルは，杭の変形を直接評価できるモデル であり，杭一地盤系のせん断ばねは杭の水平剛性と地盤反力の影響 を，ロッキングばねは杭の鉛直剛性，表層地盤の鉛直剛性，表層地 盤の摩擦抵抗，および支持地盤の地盤反力の影響を含んでいる。杭 の損傷は，杭一地盤系のせん断ばねとロッキングばねの剛性変化に 着目して検出する。入力は杭支持地盤表面の水平動とし, 回転入力 は考慮しない。このとき，運動方程式は次式のようになる。

$$
\begin{aligned}
& {\left[\begin{array}{ccc}
M_{b} & 0 & 0 \\
0 & M_{p s} & 0 \\
0 & 0 & I
\end{array}\right]\left\{\begin{array}{l}
\ddot{x}_{t s} \\
\ddot{x}_{p s} \\
\ddot{\theta}
\end{array}\right]+\left[\begin{array}{ccc}
C_{b} & -C_{b} & -C_{b} H \\
-C_{b} & C_{b}+C_{p s} & C_{b} H \\
-C_{b} H & C_{b} H & C_{r}+C_{b} H^{2}
\end{array}\right]\left\{\begin{array}{c}
\dot{x}_{t s} \\
\dot{x}_{p s} \\
\dot{\theta}
\end{array}\right\}} \\
& +\left[\begin{array}{ccc}
K_{b} & -K_{b} & -K_{b} H \\
-K_{b} & K_{b}+K_{p s} & K_{b} H \\
-K_{b} H & K_{b} H & K_{r}+K_{b} H^{2}
\end{array}\right]\left\{\begin{array}{c}
x_{t s} \\
x_{p s} \\
\theta
\end{array}\right\}=\left\{\begin{array}{c}
-M_{b} \ddot{z} \\
-M_{p s} \ddot{z} \\
0
\end{array}\right\}
\end{aligned}
$$

ここに, $x_{t s}=x_{g}+x_{s}+H \theta+x_{b}$ と $x_{p s}=x_{g}+x_{s}$ はそれぞれ支持地盤に対す

ここに, $u_{g}=z+x_{g}$ は自由地盤表面の変位, $x_{t f}=x_{s}+H \theta+x_{b}$ は自由地 盤に対する上部構造頂部の相対変位, $M_{f}$ と $M_{e g}$ はそれぞれ基礎版 の質量と杭一地盤系の等価質量である。ここでも, 上部構造の回転 慣性の影響は無視している。このとき, 杭一地盤系の等価質量に自 由地盤の加速度 $\ddot{u}_{g}$ は関係しないことに注意を要する ${ }^{16)}$ 。

\section{3. 段階的システム同定}

\subsection{2 質点系モデルのパラメター推定}

2 質点系モデルの同定手順を図 3 に示す。上部構造の質量 $M_{b}$, 基礎版の回転慣性 $I$, 上部構造の有効高さ $H$ を既知パラメターとし, 上部構造, ロッキングばね, 杭一地盤系それぞれの剛性と減衰係数 $\left(K_{b}, C_{b}, K_{r}, C_{r}, K_{p s}, C_{p s}\right)$ および杭一地盤系の有効質量 $M_{p s}$ を段 階的に同定する。 


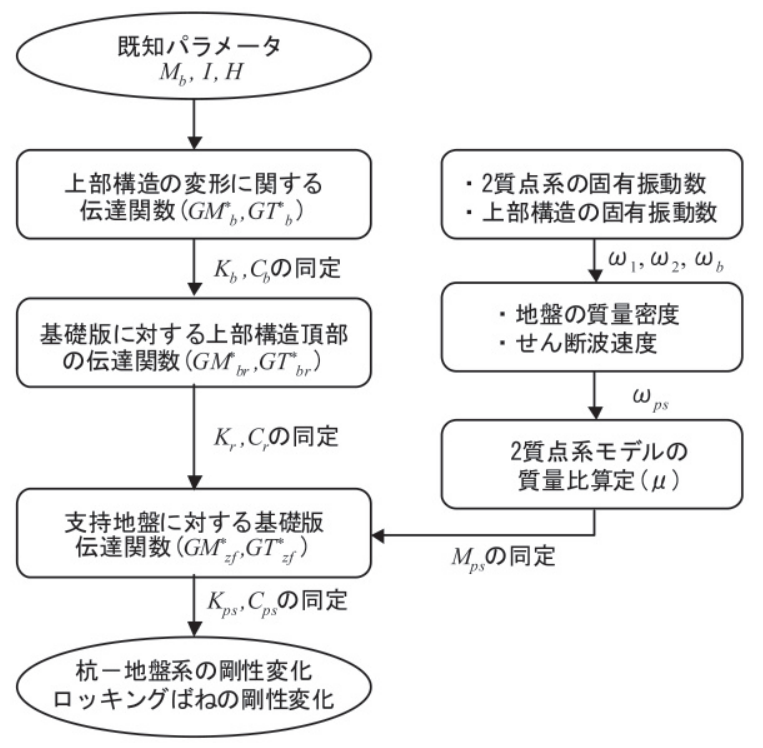

図３２質点系モデルの同定手順

最小二乗法を用いて同定モデルの理論伝達関数を計測伝達関数に 曲線適合させることにより，未知パラメターを段階的に同定する。 まず，上部構造の剛性と減衰を同定することにより，上部構造と杭 一地盤系を分離する。次に, 上部構造の剛性と減衰を既知パラメ ターとし，ロッキングばねの剛性と減衰を同定する。さらに，上部 構造とロッキングばねの剛性と減衰を既知パラメターとし, 杭一地 盤系の剛性と減衰を同定する。

2 質点系モデルにおける杭 - 地盤系の有効質量 $M_{p s}$ の同定は以下 の手順で行う。簡単のために, 回転ばねと減衰を無視したときの 2 質点系モデルの 1 次と 2 次の固有円振動数は次式で与えられる ${ }^{17)}$ 。

$$
\omega_{1,2}^{2}=\frac{1}{2}\left[\omega_{p s}^{2}+(1+\mu) \omega_{b}^{2} \mp \sqrt{\left[\omega_{p s}^{2}+(1+\mu) \omega_{b}^{2}\right]^{2}-4 \omega_{p s}^{2} \omega_{b}^{2}}\right]
$$

ここに, $\omega_{1}$ と $\omega_{2}$ はそれぞれ 1 次と 2 次の固有円振動数, $\mu=M_{b} / M_{p s}$ は質量比, $\omega_{p s}=\sqrt{K_{p s} / M_{p s}}$ は杭 - 地盤系の固有円振動数（上部構造 なし), $\omega_{b}=\sqrt{K_{b} / M_{b}}$ は基礎固定系の上部構造の固有円振動数であ る。 $\omega_{1}$ と $\omega_{2}$ は計測值から読み取り, $\omega_{b}$ は上部構造の伝達関数の ピーク振動数として求め, $\omega_{p s}$ は表層地盤のせん断波速度と深さ $(1 / 4$ 波長）から算定した。 $\omega_{1}, \omega_{2}, \omega_{b}, \omega_{p s}, M_{b}$ の值を式(3)に代入する ことにより質量比 $\mu$ を算定し, 杭一地盤系の有効質量 $M_{p s}$ を決定す る。

\subsection{SR モデルのパラメター推定}

SR モデルの同定手順を図 4 に示す。上部構造の質量 $M_{b}$, 基礎版 の質量 $M_{f}$ と回転慣性 $I$, 上部構造の高さ $H$ を既知パラメターとし て，上部構造，ロッキングばね，スウェイばねそれぞれの剛性と減 衰係数 $\left(K_{b}, C_{b}, K_{r}, C_{r}, K_{s}, C_{s}\right)$ および地盤の等価質量 $M_{e g}$ を 2 質点系モデルの場合と同様に段階的に同定する。

まず，上部構造の剛性と減衰を同定することにより上部構造を分 離する。次に, 上部構造の剛性と減衰を既知パラメターとして, ロッ キングばねの剛性と減衰を同定する。さらに，上部構造とロッキン グばねの剛性と減衰を既知バラメターとしてスウェイばねの剛性と 減衰を同定する。

$\mathrm{SR}$ モデルの入力として用いる自由地盤表面の水平加速度は, 実

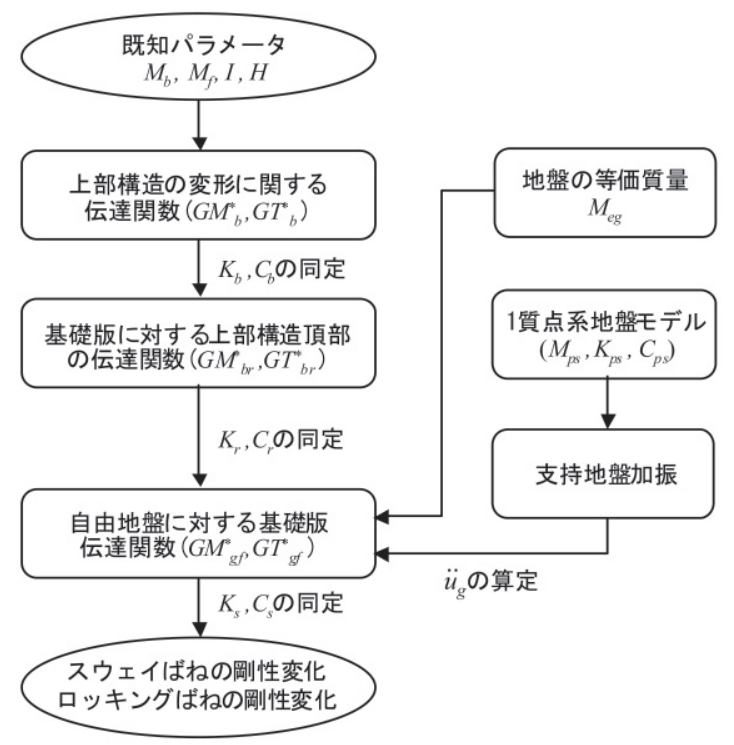

図 4 SR モデルの同定手順

際には建物周辺に広大な地表面が広がっていない限り計測すること は難しい。本研究では, SR モデルで用いる自由地盤表面の水平加 速度を, 上部構造と杭－地盤系の 2 質点系モデルの同定を行った後, その上部構造を取り去って得られる 1 自由度系モデルに対して, 杭 支持地盤での水平加速度を入力することにより求める。

\section{4. 計測伝達関数}

加速度センサの設置位置で計測される加速度を図 5 に示す。これ らの計測值を用いて計測伝達関数を求める。

\section{1 上部構造の変形とロッキングに関する計測伝達関数}

2 質点系モデルと SR モデルの上部構造の変形に関する伝達関数 は, ともに上部構造頂部と基礎版の水平動, および基礎版両端の上 下動を計測することにより求められる。基礎版に対する上部構造頂 部の伝達関数は, 水平加速度 $\ddot{H}_{f}$ に対する $\ddot{H}_{b}$ のフーリエスペクト ル比をとることにより次式で与えられる。この伝達関数にはロッキ ングの影響が含まれている。

$$
G M_{b r}^{*}(\omega)=\frac{\ddot{Z}(\omega)+\ddot{X}_{g}(\omega)+\ddot{X}_{s}(\omega)+H \ddot{\theta}(\omega)+\ddot{X}_{b}(\omega)}{\ddot{Z}(\omega)+\ddot{X}_{g}(\omega)+\ddot{X}_{s}(\omega)}
$$

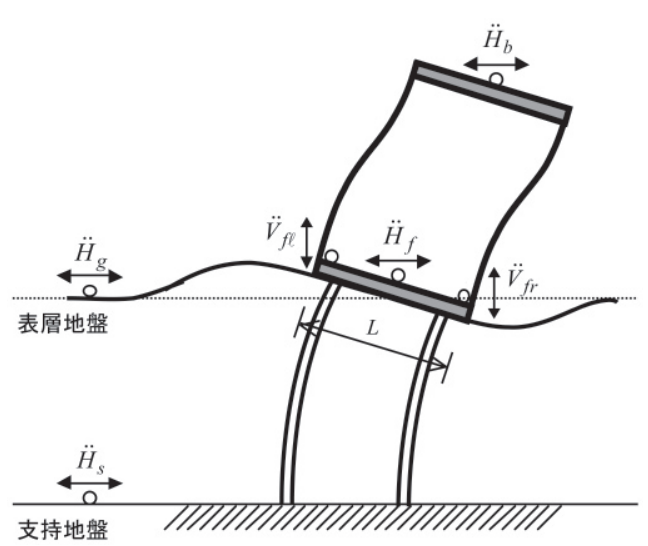

図 5 加速度センサの設置位置における加速度 
ここに， *は複素数であることを表し，基礎版の回転角 $\theta(\omega)$ は基 礎版両端の上下動時刻歴から以下のように算出した $\theta(t)$ のフーリ エ変換である。

$$
\theta(t)=\frac{V_{f t}(t)-V_{f r}(t)}{L}
$$

ここに, $V_{f}(t)$ と $V_{f r}(t)$ はそれぞれ基礎版の左端と右端での上下変 位，Lは基礎版の幅である。

式(4)からロッキングの影響を除いた上部構造の変形のみに関する 伝達関数は次式で与えられる。

$$
G M_{b}^{*}(\omega)=\frac{\ddot{Z}(\omega)+\ddot{X}_{g}(\omega)+\ddot{X}_{s}(\omega)+H \ddot{\theta}(\omega)+\ddot{X}_{b}(\omega)}{\ddot{Z}(\omega)+\ddot{X}_{g}(\omega)+\ddot{X}_{s}(\omega)+H \ddot{\theta}(\omega)}
$$

\subsection{2 質点系モデルにおける杭一地盤系の計測伝達関数}

2 質点系モデルの場合, 支持地盤に対する上部構造頂部の伝達関 数は, 水平加速度 $\ddot{H}_{s}$ に対する $\ddot{H}_{b}$ のフーリエスペクトル比として 次式で与えられる。

$$
G M_{z b}^{*}(\omega)=\frac{\ddot{Z}(\omega)+\ddot{X}_{g}(\omega)+\ddot{X}_{s}(\omega)+H \ddot{\theta}(\omega)+\ddot{X}_{b}(\omega)}{\ddot{Z}(\omega)}
$$

また，支持地盤に対する基礎版の伝達関数は，水平加速度 $\ddot{H}_{s} に$ 対 する $\ddot{H}_{f}$ のフーリエスペクトル比として次式で与えられる。

$$
G M_{z f}^{*}(\omega)=\frac{\ddot{Z}(\omega)+\ddot{X}_{g}(\omega)+\ddot{X}_{s}(\omega)}{\ddot{Z}(\omega)}
$$

\subsection{SR モデルにおける杭一地盤系の計測伝達関数}

$\mathrm{SR}$ モデルの場合, 自由地盤に対する上部構造頂部の伝達関数は, 水平加速度 $\ddot{H}_{g}$ に対する $\ddot{H}_{b}$ のフーリエスペクトル比として次式で 与えられる。

$$
G M_{g b}^{*}(\omega)=\frac{\ddot{Z}(\omega)+\ddot{X}_{g}(\omega)+\ddot{X}_{s}(\omega)+H \ddot{\theta}(\omega)+\ddot{X}_{b}(\omega)}{\ddot{Z}(\omega)+\ddot{X}_{g}(\omega)}
$$

また, 自由地盤に対する基礎版の伝達関数は, 水平加速度 $\ddot{H}_{g}$ に対 する $\ddot{H}_{f}$ のフーリエスペクトル比として次式で与えられる。

$$
G M_{g f}^{*}(\omega)=\frac{\ddot{Z}(\omega)+\ddot{X}_{g}(\omega)+\ddot{X}_{s}(\omega)}{\ddot{Z}(\omega)+\ddot{X}_{g}(\omega)}
$$

\section{5. 理論伝達関数}

\section{1 上部構造の変形とロッキングに関する理論伝達関数}

基礎版に対する上部構造頂部の理論伝達関数は，2 質点系モデル の場合, 連立方程式(1)を $x_{t s}$ と $x_{b s}$ に関して解き, 式(4)に代入するこ とにより求まる。SR モデルの場合も同様に, 連立方程式(2)を $x_{t f}$ と $x_{s}$ に関して解き，式(4)に代入することにより求まる。最終的に， 2 質点系モデル，SR モデルともに次式で与えられる。

$$
G T_{b r}^{*}(\omega)=\frac{-K_{b}^{*}}{M_{b} \omega^{2}-K_{b}^{*}+\frac{M_{b} \omega^{2} K_{b}^{*} H^{2}}{-I \omega^{2}+K_{r}^{*}}}
$$

ここに, $K_{b}^{*}$ と $K_{r}^{*}$ はそれぞれ上部構造の変形とロッキングばねの 複素剛性で以下のように与えられる。

$$
K_{b}^{*}=K_{b}+i \omega C_{b}
$$

$$
K_{r}^{*}=K_{r}+i \omega C_{r}
$$

式(11)からロッキングの影響を除いた伝達関数は, 連立方程式(1)を $x_{t s}, x_{p s}, \theta$ に関して解き, 式(6)に代入することにより求まる。SR モ デルの場合も同様に, 連立方程式(2)を $x_{t}, x_{s}, \theta$ に関して解き, 式 (6)に代入することにより求まる。最終的に， 2 質点系モデル， SR モデルともに次式で与えられる。

$$
G T_{b}^{*}(\omega)=\frac{-K_{b}^{*}}{M_{b} \omega^{2}-K_{b}^{*}}
$$

\subsection{2質点系モデルにおける杭一地盤系の理論伝達関数}

2 質点系モデルの場合, 支持地盤に対する上部構造頂部の伝達関 数は, 連立方程式(1)を解いて $x_{t s}$ を求め, 式(7)に代入することによ り次式で与えられる。

$$
G T_{z b}^{*}(\omega)=\frac{\frac{-K_{b}^{*} K_{p s}^{*}}{-M_{p s} \omega^{2}+K_{p s}^{*}}}{M_{b} \omega^{2}-K_{b}^{*}+\frac{M_{b} \omega^{2} K_{b}^{*}}{-M_{p s} \omega^{2}+K_{p s}^{*}}+\frac{M_{b} \omega^{2} K_{b}^{*} H^{2}}{-I \omega^{2}+K_{r}^{*}}}
$$

ここに， $K_{p s}^{*}$ は次式で定義される杭一地盤系の複素剛性である。

$$
K_{p s}^{*}=K_{p s}+i \omega C_{p s}
$$

同様に, 支持地盤に対する基礎版の理論伝達関数は, 連立方程式 (1)を解いて $x_{p s}$ を求め, 式(8)に代入することにより次式で与えられ る。

$$
\begin{aligned}
G T_{z f}^{*}(\omega)= & \frac{K_{p s}^{*}}{-M_{p s} \omega^{2}+K_{p s}^{*}} \\
& +\frac{\frac{-M_{b} \omega^{2} K_{b}^{*} K_{p s}^{*}}{\left(-M_{p s} \omega^{2}+K_{p s}^{*}\right)^{2}}}{M_{b} \omega^{2}-K_{b}^{*}+\frac{M_{b} \omega^{2} K_{b}^{*}}{-M_{p s} \omega^{2}+K_{p s}^{*}}+\frac{M_{b} \omega^{2} K_{b}^{*} H^{2}}{-I \omega^{2}+K_{r}^{*}}}
\end{aligned}
$$

\subsection{SR モデルにおける杭一地盤系の理論伝達関数}

SR モデルの場合, 自由地盤に対する上部構造頂部の伝達関数は, 連立方程式(2)を解いて $x_{t f}$ を求め, 式(9)に代入することにより次式 で与えられる。

$$
G T_{g b}^{*}(\omega)=\frac{\frac{K_{b}^{*} M_{e g} \omega^{2}-K_{b}^{*} K_{s}^{*}}{-\left(M_{f}+M_{e g}\right) \omega^{2}+K_{s}^{*}}}{M_{b} \omega^{2}-K_{b}^{*}+\frac{M_{b} \omega^{2} K_{b}^{*}}{-\left(M_{f}+M_{e g}\right) \omega^{2}+K_{s}^{*}}+\frac{M_{b} \omega^{2} K_{b}^{*} H^{2}}{-I \omega^{2}+K_{r}^{*}}}
$$

ここに， $K_{s}^{*}$ は次式で定義されるスウェイばねの複素剛性である。

$$
K_{s}^{*}=K_{s}+i \omega C_{s}
$$

同様に, 自由地盤に対する基礎版の理論伝達関数は, 連立方程式 (2)を解いて $x_{s}$ を求め, 式(10)に代入することにより次式で与えられ る。

$$
\begin{aligned}
G T_{g f}^{*}(\omega)= & \frac{K_{s}^{*}-M_{e g} \omega^{2}}{-\left(M_{f}+M_{e g}\right) \omega^{2}+K_{s}^{*}} \\
& +\frac{\frac{M_{b} \omega^{2} K_{b}^{*} M_{e g} \omega^{2}-M_{b} \omega^{2} K_{b}^{*} K_{s}^{*}}{\left\{-\left(M_{f}+M_{e g}\right) \omega^{2}+K_{s}^{*}\right\}^{2}}}{M_{b} \omega^{2}-K_{b}^{*}+\frac{M_{b} \omega^{2} K_{b}^{*}}{-\left(M_{f}+M_{e g}\right) \omega^{2}+K_{s}^{*}}+\frac{M_{b} \omega^{2} K_{b}^{*} H^{2}}{-I \omega^{2}+K_{r}^{*}}}
\end{aligned}
$$




\section{6. 理論伝達関数と計測伝達関数の曲線適合 \\ 6.1 計測伝達関数の前処理}

物理パラメターの推定は, 理論伝達関数を計測伝達関数に曲線適 合させることにより行う ${ }^{18)}$ 。本研究で用いる 2 質点系モデルと SR モデルの理論伝達関数はせいぜい二山を有する形状であるが, 生 データの計測伝達関数は様々なノイズを含み多峰の複雑な形状とな る。このため, 計測伝達関数にフィルターをかけて平滑化し, 理論 伝達関数への曲線適合の安定化を図る。ここでは, 計測した全時系 列デー夕をオーバーラップさせた 20 個のセグメント（データ数 2048）に分け，フーリエ変換したものをスタッキング（重ね合せ） した後，4つおきのデータ点を以下の 3 次スプライン関数 ${ }^{19)}$ で補間 して平滑化を行った。

$$
S_{j}(\omega)=a_{j}+b_{j}\left(\omega-\omega_{j}\right)+c_{j}\left(\omega-\omega_{j}\right)^{2}+d_{j}\left(\omega-\omega_{j}\right)^{3}
$$

ここに, $S_{j}(\omega)$ は区間 $\left[\omega_{j}, \omega_{j+1}\right]$ で定義されるスプライン関数， $a_{j}$, $b_{j}, c_{j}, d_{j}$ は未定係数である。図 6 に無損傷状態の場合を例として, 計測伝達関数の前処理の過程を示す。

\section{2 最急降下法による最適化}

前処理を行った後, 最小二乗法を用いて, 数学モデルの物理パラ メターを同定する。理論伝達関数と計測伝達関数の誤差を最小化す るために用いる目的関数を次式で定義する。

$$
J(K, C)=\int_{\omega_{\mathrm{e}}}^{\omega_{u}}\{G T(\omega)-G M(\omega)\}^{2} d \omega
$$

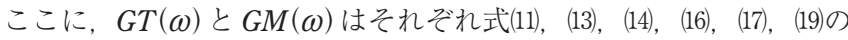
理論伝達関数と式(4)，(6)，(7)，(8)，(9)，(10)の計測伝達関数の振幅 （複素伝達関数の実部と虚部の 2 乗和平方根）を表し， $\omega_{\ell}$ と $\omega_{u}$ は それぞれ考慮する振動数範囲の最小振動数と最大振動数である。周 波数の重みはとくにつけず重み均等として最適化を行う。位相は曲 線適合には用いず，伝達関数における 2 つのピーク振動数の確認の ために利用した。

理論伝達関数の物理パラメターは式(21)を最小化することにより求 める。最小化手法には最急降下法 ${ }^{20)}$ を用いる。以下のように剛性 $K$ と減衰 $C$ を繰り返し更新して最適な $K$ と $C$ を同定する。

$$
\left[\begin{array}{l}
K^{(i+1)} \\
C^{(i+1)}
\end{array}\right]=\left[\begin{array}{l}
K^{(i)} \\
C^{(i)}
\end{array}\right]+a^{(i)}\left[\begin{array}{l}
d_{k}^{(i)} \\
d_{c}^{(i)}
\end{array}\right]
$$

ここに, $i$ は反復回数, $a^{(i)}$ はステップ幅であり, 通常は収束効率を

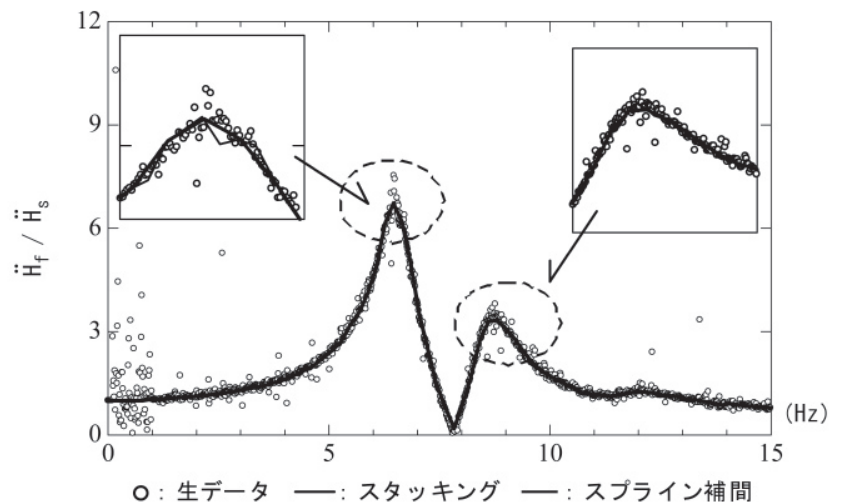

図6 計測伝達関数の前処理の例
高めるために, 収束点から遠いときは大きな值，近づくほど小さな 值を与える。本研究では, 収束状況を追跡しながら $0.1 \sim 0.001$ の範 囲の值を用いた。 $d_{k}$ と $d_{c}$ は最急降下方向ベクトル成分であり，そ れぞれ次式で与えられる。

$$
d_{k}=-\frac{\partial J(K, C)}{\partial K} \quad(23 \mathrm{a}) \quad d_{c}=-\frac{\partial J(K, C)}{\partial C}
$$

繰り返し計算における収束条件は次式で与えた。

$$
\frac{J(K, C)}{\int_{\omega_{\ell}}^{\omega_{u}} G M(\omega) d \omega}<\eta
$$

ここに, $\eta$ は収束パラメターである。

\section{7. 模型振動台実験}

\section{1 実験模型}

実験模型の概要を図 7 に示す。地盤模型は $1000 \times 300 \times 270 \mathrm{~mm}$ の 直方体であり，シリコンを用いて支持地盤と表層地盤に物性を分け て作成した。支持地盤と表層地盤の設計せん断波速度はそれぞれ

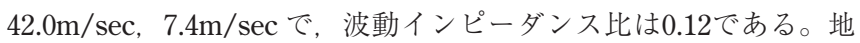
盤の振動方向の両端下端をヒンジ機構としたアルミニウム板を可倒 壁として設置し， 2 枚の可倒壁の上端部をアルミニウム棒で連結し て地盤のせん断変形を模擬した。なお，地盤模型の製作に関しては 文献 ${ }^{21,22)}$ を参考にした。

上部構造の模型は, 上部構造の質量を集約した厚さ $15 \mathrm{~mm}$ の鉄板, 上部構造の剛性を集約した計 4 枚の鋼板ばね $(25 \times 1.8 \times 250 \mathrm{~mm})$, および厚さ $20 \mathrm{~mm}$ のアルミニウム製基礎版で構成した。杭は計 4 本 で, $\phi 15 \mathrm{~mm}$, 長さ $250 \mathrm{~mm}$ のアクリル製とし，それぞれ板ばねの真 下に設置し，杭端の $10 \mathrm{~mm}$ は硬質シリコンに埋め込んた。 上部構造 模型の固有振動数は地盤の固有振動数に近接させ, 上部構造の応答 増幅による慣性効果が大きくなるように設計した。実験模型の相似 則を表 1 に示す。なお, 実験で用いたアクリル杭，表層地盤シリコ ン，支持地盤シリコンのヤング係数とポアソン比は，それぞれ 3.0 $\times 10^{9} \mathrm{~N} / \mathrm{m}^{2}$ と $0.35,1.7 \times 10^{5} \mathrm{~N} / \mathrm{m}^{2}$ と $0.49,7.5 \times 10^{6} \mathrm{~N} / \mathrm{m}^{2}$ と0.49である。 杭先端を支持地盤に埋め込むために，まず不透明な硬質シリコン を $10 \mathrm{~mm}$ 打設し, 杭の先端位置を決定してから杭を挿入し, さらに $10 \mathrm{~mm}$ 打設した後，透明な軟質シリコンを気泡が生じないように ゆっくりと打設した。杭の損傷状態の設定を変えるたびに, 杭周辺 の軟質シリコンを以下の手順で入れ替えた。まず，基礎版の長辺方 向端部から $30 \mathrm{~mm}$ 離れた位置で軟質シリコンを切断して上部構造と 杭を取り出し, 杭間の幅 $100 \mathrm{~mm}$ の中央部の軟質シリコンを再利用 した。杭を設置し直した後, 杭周辺の間隙に軟質シリコンを新規に 打設した。地盤材料が十分固化して設計時の剛性が発現するまで 24 時間放置した後，実験を開始した。

\section{2 損傷状態の設定}

杭の模擬損傷の設定を図 8 に示す。杭頭付近を長さ $40 \mathrm{~mm}$ にわた り断面を $\phi 7 \mathrm{~mm}$ と小さくすることにより杭頭損傷を, 杭中間部を 長さ $60 \mathrm{~mm}$ にわたり断面を $\phi 7 \mathrm{~mm}$ と小さくすることにより杭中間 部損傷を模擬した。また, 杭頭の損傷部を手で折って杭頭部破断を 模擬した。破断面は平滑な斜面になった。

地盤材料を打設してから固化するまでの時間を節約するために， 
表 1 実験模型の相似則

\begin{tabular}{|l|l|l|}
\hline 緒元 & 次元 & 相似比 \\
\hline 長さ & $\mathrm{L}$ & $1 / 50$ \\
\hline 質量 & $\mathrm{M}$ & $1 / 150000$ \\
\hline 時間 & $\mathrm{T}$ & $1 / 7.071$ \\
\hline 速度 & $\mathrm{LT}^{-1}$ & $1 / 7.071$ \\
\hline 加速度 & $\mathrm{LT}^{-2}$ & $1 / 1$ \\
\hline 振動数 & $\mathrm{T}^{-1}$ & $7.071 / 1$ \\
\hline 密度 & $\mathrm{ML}^{-3}$ & $1 / 1.2$ \\
\hline
\end{tabular}

\begin{tabular}{|l|l|l|}
\hline 緒元 & 次元 & 相似比 \\
\hline 重量 & $\mathrm{MLT}^{-2}$ & $1 / 150000$ \\
\hline モーメント & $\mathrm{ML}^{2} \mathrm{~T}^{-2}$ & $1 / 150000 \times 50$ \\
\hline 断面積 & $\mathrm{L}^{2}$ & $1 / 2500$ \\
\hline 弾性定数 & $\mathrm{ML}^{-1} \mathrm{~T}^{-2}$ & $1 / 60$ \\
\hline ばね定数 & $\mathrm{MT}^{-2}$ & $1 / 3000$ \\
\hline ポアソン比 & --- & $1 / 1$ \\
\hline 減衰定数 & --- & $1 / 1$ \\
\hline \multicolumn{3}{|c|}{ (注)*は設定相似比を示す。 } \\
\hline
\end{tabular}

2 つの地盤模型（試験体 A，試験体 B）を作製し，交互に振動台に 載せて実験を行った。各試験体に対し，表 2 と図 8 に示すような損 傷状態を設定した。すなわち，無損傷状態，杭頭 2 本損傷，杭頭 4 本損傷，杭頭 2 本破断，杭中間部 2 本損傷，杭中間部 4 本損傷の全 6ケースを考慮した。

\section{3 振動計測}

振動台実験に打ける入力は， $0.5 \sim 50 \mathrm{~Hz}$ の带域限定ホワイトノイ ズとした。加振時間は杭の各損傷状態に対し100秒とした。加速度 センサの位置と方向は, 図 7 に示すように, 上部構造頂部の水平動, 基礎版の水平動，基䃈版両端部の上下動，地盤表面の水平動，振動 台上（基盤）の水平動とした。

\section{4 地盤模型の振動}

上部構造がある場合とない場合について，Case4を例として地盤 上と基礎版上での加速度フーリエスペクトルを図 9 に示す。上部構 造がない場合，地盤表面と基礎版の形状はほほ同じであり，基礎版 が慣性力の大きな地盤の卓越周期に追随して振動しており，上部構 造がない場合の基礎版の振動は自由地盤の振動とほぼ同じと考える ことができる。一方，上部構造がある場合，上部構造の慣性力の影 響により地盤表面と基礎版のスペクトル形状は変化し, 自由地盤波 形とはいえなくなっている。

\section{8. 同定結果と検討}

2つの数学モデルにより杭の剛性低下に着目して損傷を推定した 結果を以下に示す。両モデルに扔ける既知パラメターの值は， $M_{b}$ $=2.52 \mathrm{~kg}, \quad M_{f}=1.08 \mathrm{~kg}, I=0.0045 \mathrm{kgm}^{2}$ である。

\section{1 試験体 A と試験体 B の振動特性}

上部構造がないときの試験体 $\mathrm{A}$ と試験体 $\mathrm{B}$ について, 振動台に 対する地盤表面の伝達関数を図10に示す。試験体 $\mathrm{A}$ と試験体 B に おける地盤の卓越振動数はそれぞれ $7.63 \mathrm{~Hz}$ と $7.93 \mathrm{~Hz}, 1 / \sqrt{2}$ 法で求 めた減衰比は 0.077 と0.092 となった。実験に用いた軟質シリコンの

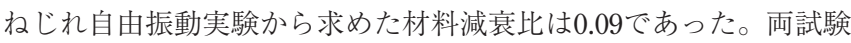
体の固有振動数と減衰比が異なる原因は，地盤打設時の硬化剂の混
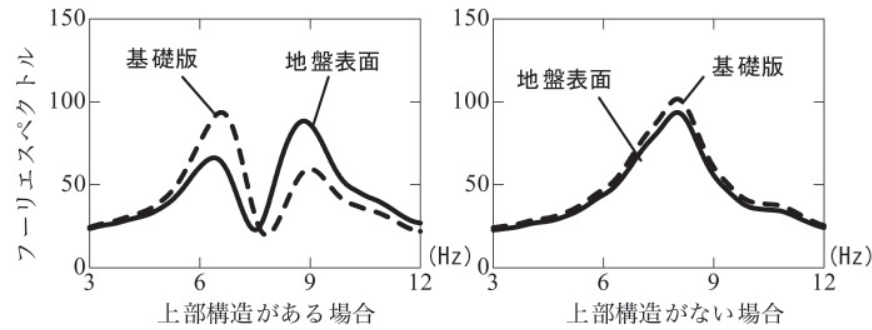

図 9 地盤表面と基礎版の加速度フーリエスペクトルの例
表 2 杭の損傷パターン $(\bigcirc$ : 無損傷 損傷 $\times$ : 破断)

\begin{tabular}{|c|c|c|c|c|c|c|}
\hline \multicolumn{3}{|c|}{ 損傷状態 杭位置 } & (1) & (2) & (3) & (4) \\
\hline \multirow{3}{*}{ 試験体A } & Case1 & 無損傷状態 & $\mathrm{O}$ & $\mathrm{O}$ & $\mathrm{O}$ & $\mathrm{O}$ \\
\hline & Case2 & 杭頭部 2 本損傷 & O & O & $\mathrm{O}$ & $\mathrm{O}$ \\
\hline & Case3 & 杭頭 2 本破断 & $x$ & $x$ & $\mathrm{O}$ & $\mathrm{O}$ \\
\hline \multirow{3}{*}{ 試験体B } & Case4 & 杭中間部 2 本損傷 & ○ & 0 & $\mathrm{O}$ & O \\
\hline & Case5 & 杭中間部4本損傷 & O & ○ & O & ○ \\
\hline & Case6 & 杭頭部 4 本損傷 & O & O & O & 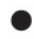 \\
\hline
\end{tabular}
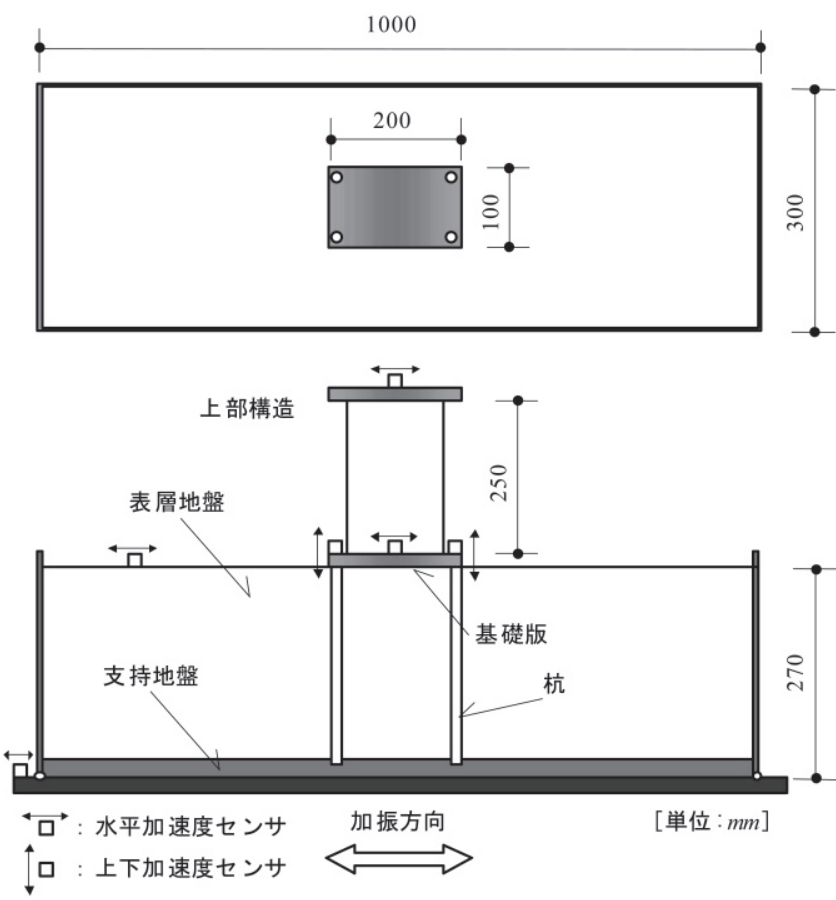

図 7 実験模型の概要
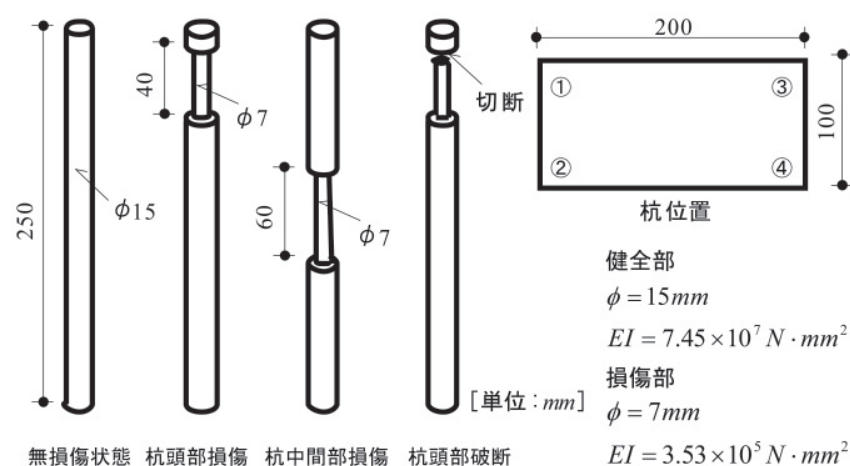

$E I=3.53 \times 10^{5} \mathrm{~N} \cdot \mathrm{mm}^{2}$

図8 杭の模擬損傷の設定

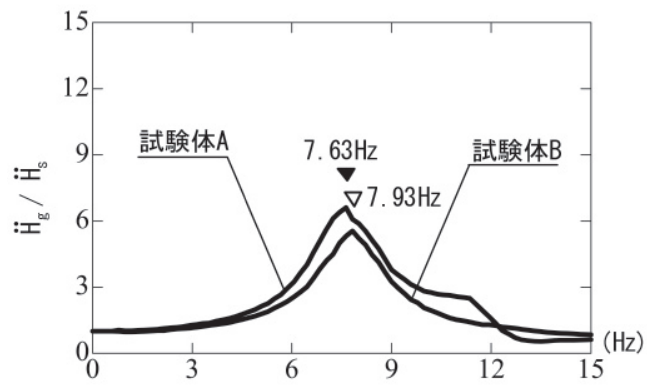

図10 試験体 A と B における地盤の振動特性 
入量と混合方法のばらつきによるものと考えられる。このため，本 研究では試験体 $\mathrm{A}$ と試験体 B それぞれの損傷状態の結果を示した 後, 両試験体の地盤剛性の調整を行って, 全損傷状態に対する同定 值の変化を比較検討した。なお，相互作用効果の指標としてのスウェ イ率とロッキング率の值は, 1 次固有振動数においてそれぞれ 8 (無 損傷）～14 (破断) \%と 5 (無損傷) 〜 20 (破断) \%であった。

\section{2 上部構造の变形に関する同定}

式(6)の計測伝達関数と式(13)の理論伝達関数の収束時の形状を図 11 に示す。収束パラメターは $\eta=0.02$ と設定した。上部構造の変形に 関する伝達関数はいずれもピーク振動数が $8.0 \mathrm{~Hz}$ であり, 試験体 $\mathrm{A}$ と試験体 B で使用した上部構造模型は同じ振動特性を有している ことがわかる。また, 上部構造の固有振動数は図10の地盤の卓越振 動数と近接しており, 共振により上部構造の応答が増幅する領域で の実験になっている。理論伝達関数の収束時のパラメター推定值を 表 3 に示す。損傷指標としての剛性低下率は, 無損傷時と損傷時の 同定值の差を無損傷時の同定值で除して求めた。試験体 A におい て, 無損傷状態 (Case1) に対して杭頭 2 本損傷状態 (Case2) と 杭頭 2 本破断状態（Case3）の剛性変化は見られなかった。試験体 B においても，杭中間部 2 本損傷状態（Case4）に対して杭中間部 4 本損傷状態（Case5） と杭頭 4 本損傷状態（Case6）の剛性変化 は見られなかった。試験体 A と試験体 B ともに, 杭の損傷状態に よらず上部構造の固有振動数は同じ值を示しており, いずれのケー スも上部構造には損傷が生じていないことが確認できる。

\section{Case1：無損傷}
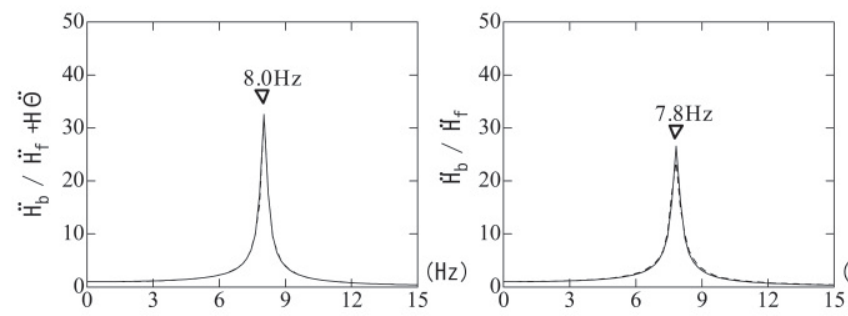
$(\mathrm{Hz})$

Case3: 杭頭2本破断
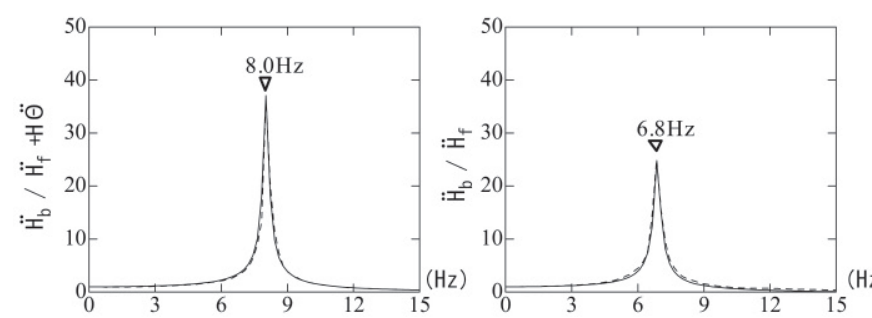

Case5：杭中間部4本損傷
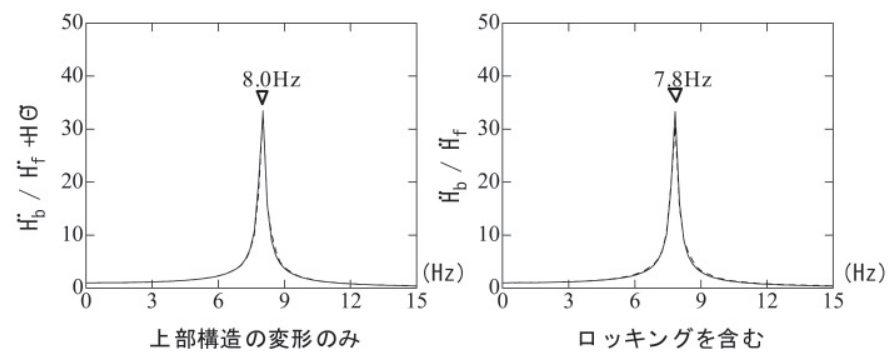

上部構造の変形のみ

\section{3 ロッキングばねの同定}

式(4)の計測伝達関数と式(11)の理論伝達関数の収束時の形状を図 11 に示す。収束パラメターは $\eta=0.04$ と設定した。ロッキングを含む 伝達関数のピーク振動数は杭頭破断の Case3を除くすべての損傷状 態で $7.8 \mathrm{~Hz}$ であり, Case 3 み $6.8 \mathrm{~Hz}$ と大きな振動数低下が見られ た。理論伝達関数の収束時の剛性と減衰の推定値を表 4 に示す。試 験体 Aにおいて, Case1に対するCase2のロッキングばねの剛性変 化は見られないものの, 杭頭破断のCase3では大きな低下が見られ た。試験体 B においては, Case4に対するCase5と Case6のロッキ ングばねの剛性変化は見られなかった。このことから，損傷前後で のロッキングばねの剛性変化から損傷状態を推定することは難しい が，杭の破断の有無を判断するには有効なことがわかる。

\subsection{2 質点系モデルにおける杭一地盤系の同定}

式(3)により算定した質量比 $\mu$ は0.068であり, 有効質量 $M_{p s}$ は $37.1 \mathrm{~kg}$ となった。式(7)の計測伝達関数と式(14)の理論伝達関数の収束時の形 状を各損傷状態に対し図12の左側に示す。収束パラメターは $\eta=$ 0.10 と設定した。しかし， 1 次と 2 次のピーク間の谷部での適合が 十分ではなく, Case1は $\eta=0.13$, Case 2 は $\eta=0.14$, Case3は $\eta=0.21$, Case6は $\eta=0.16$ でそれぞれ収束計算を打ち切った。

式(8)の計測伝達関数と式(16)の理論伝達関数の収束時の形状を各損 傷状態に対し図12の右側に示す。収束パラメターは $\eta=0.05$ と設定 したが, 杭頭破断のCase3では収束が悪く, $\eta=0.12 て ゙$ 収束計算を 終了した。

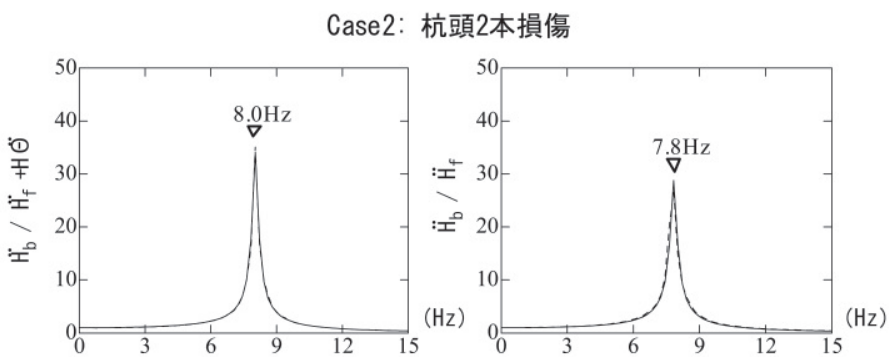

Case4：杭中間部2本損傷

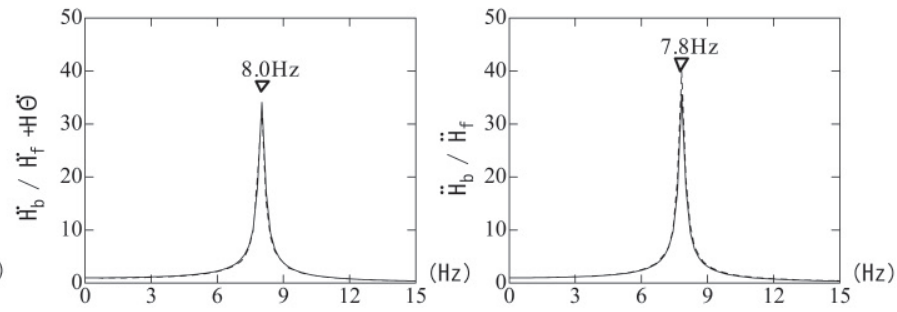

Case6：杭頭4本損傷
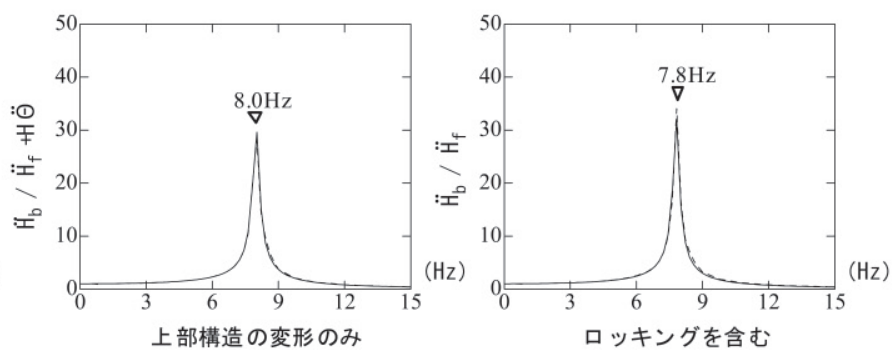

図11 上部構造に関する伝達関数の曲線適合 
Case1:無損傷
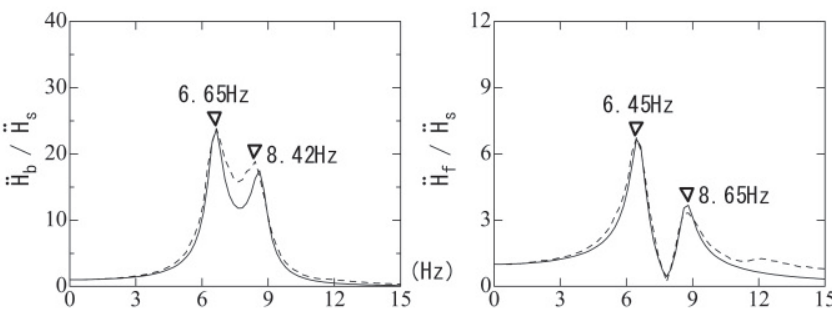

Case3：杭頭2本破断
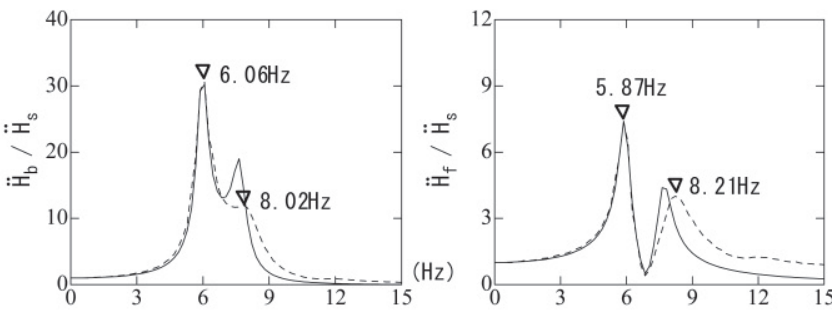

Case5：杭中間部4本損傷

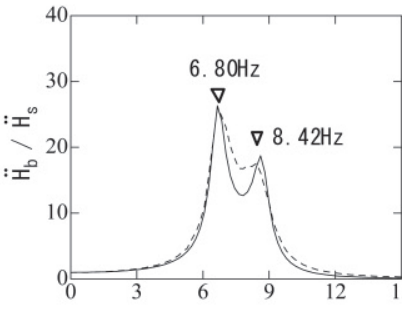

上部構造 頂部／支持地盤

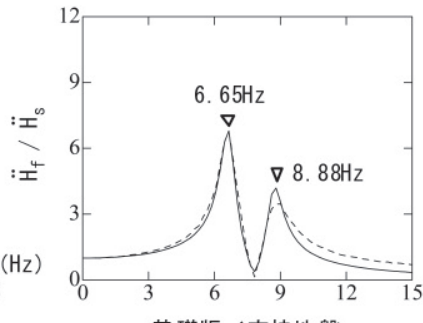

基礎版／支持地盤

図12 2 質点系モデルにおける伝達関数の曲線適合

Case 1:無損傷
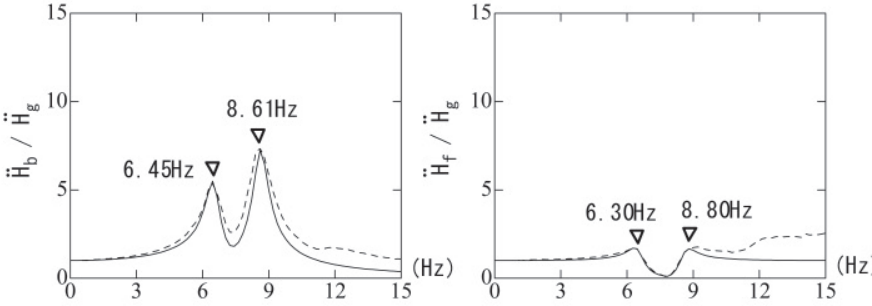

Case3：杭頭2本破断
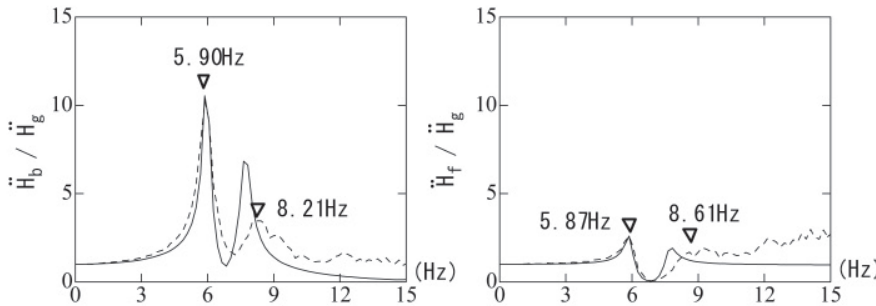

Case5：杭中間部4本損傷

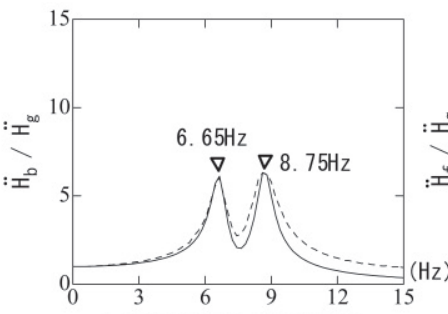

上部構造頂部 $/$ 自由地盤

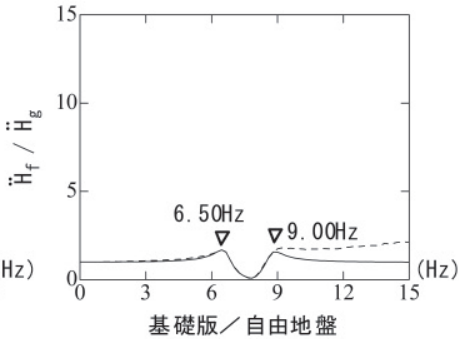

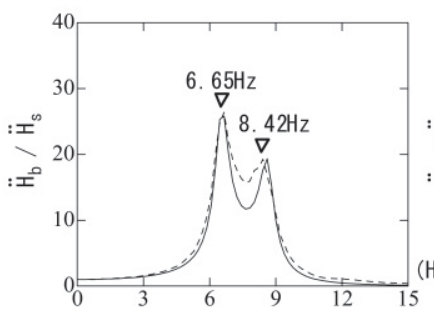

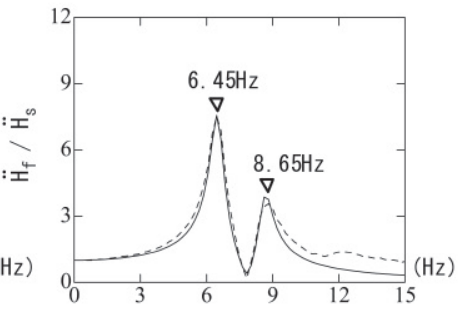

Case4：杭中間部2本損傷

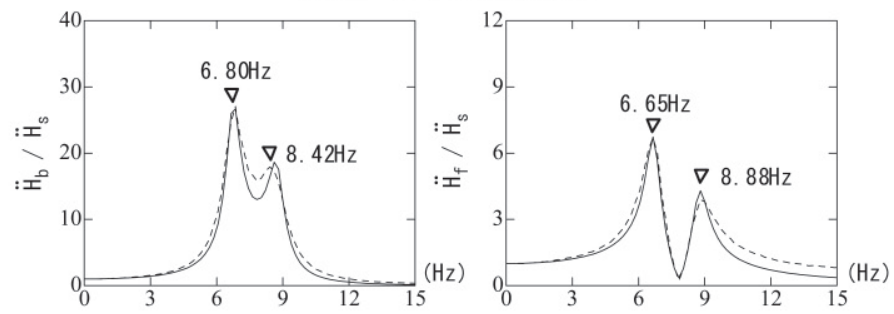

Case6：杭頭4本損傷

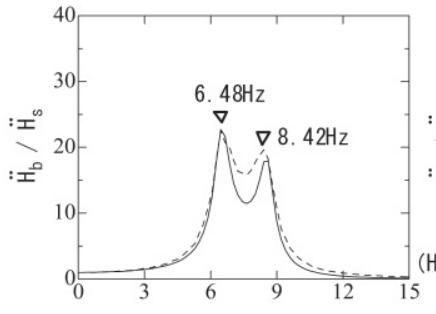

上部構造頂部／支持地盤

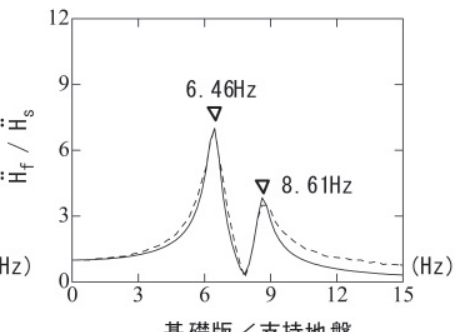

基礎版／支持地盤

: 理論伝達関数 - - - : 計測伝達関数 適合領域 : $5 \sim 10 \mathrm{~Hz}$ )

Case2：杭頭2本損傷

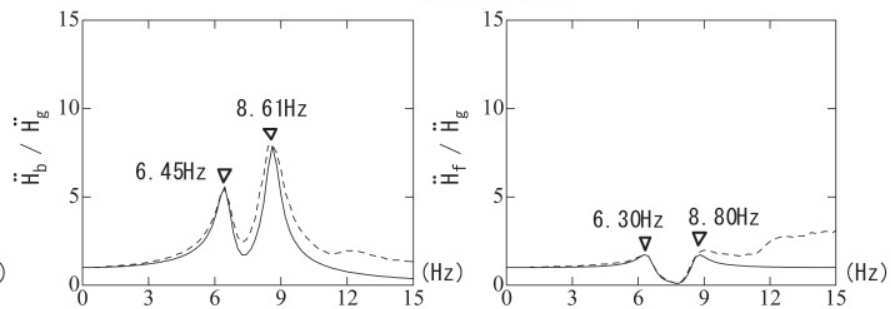

Case 4：杭中間部2本損傷

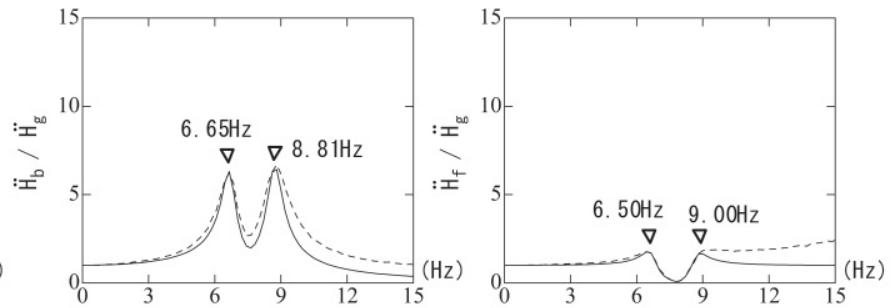

Case6：杭頭4本損傷

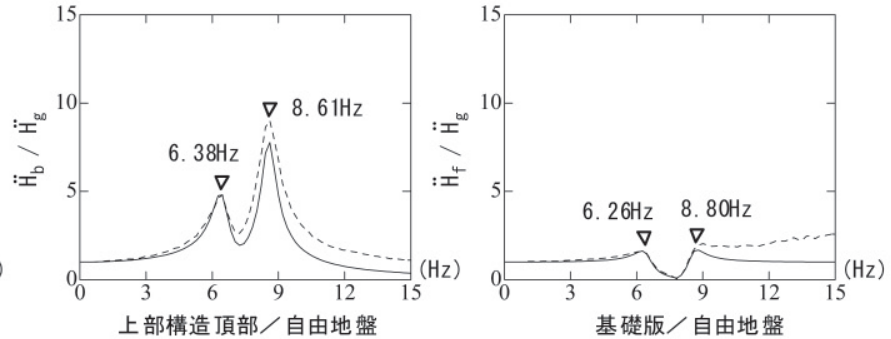

図13 SR モデルにおける伝達関数の曲線適合（——：理論伝達関数 - - - - : 計測伝達関数 適合領域 : $5 \sim 10 \mathrm{~Hz}$ ) 
両伝達関数から導かれた物理パラメターの推定值は最終的に一致 した。理論伝達関数の収束時の剛性と減衰の推定值を表 5 に示す。 試験体 Aにおいて, Case1に対するCase2 と Case3の杭一地盤系の 剛性変化から，杭の損傷状態に応じた剛性低下が確認できた。とく に，杭頭破断のCase3では剛性の大幅な低下が見られた。試験体 B においても, Case4に対するCase5とCase6の杭－地盤系の剛性変 化から，杭の損傷状態に応じた剛性低下が確認された。

試験体 A と試験体 B の結果を統一的に整理するために, 試験体 $\mathrm{B}$ の地盤を試験体 $\mathrm{A}$ の地盤に置き換えたときの剛性低下率を算定 し表 7 に示す。このとき, 図10に示す試験体 A と試験体 B の地盤 の卓越振動数から各試験体の地盤剛性を推定し, 試験体 B に対す る試験体 A の地盤剛性の比を試験体 B の各損傷状態における杭一 地盤系の剛性值に乗じることにより地盤模型間のばらつきを調整し た。

各損傷状態における杭 - 地盤系の無損傷状態からの剛性変化を比 べると，杭損傷の増大とともに，杭中間部 2 本損傷 $<$ 杭頭 2 本損傷 $<$ 杭中間部 4 本損傷 $<$ 杭頭 4 本損傷 $<$ 杭頭 2 本破断の順で剛性低下 が大きくなる傾向が見られた。杭に破断が起きた場合の剛性低下が 最も大きく，損傷状態としては杭頭損傷の方が杭中間部損傷よりも はるかに明確な剛性低下を示した。また，全て（4 本）の杭が損傷 した場合は, 一部（2本）の杭が損傷した場合に比べて大幅な剛性 低下が観察された。

\subsection{SR モデルにおける杭一地盤系の同定}

自由地盤に対する上部構造頂部の計測伝達関数のピーク振動数

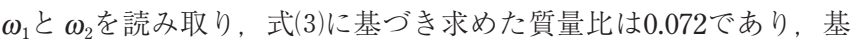
礎版に付加する等価質量 $M_{e g}$ は $33.8 \mathrm{~kg}$ となった。等価質量 $M_{e g}$ が大 きくなる現象は, 上部構造から地盤への散逸エネルギーが限定され た地盤領域に閉じ込められ，上部構造に再入力されることに対応し ている。

式(9)の計測伝達関数と式(17)の理論伝達関数の収束時の形状を各損 傷状態に対し図 13 の左側に示す。収束パラメターは $\eta=0.15$ と設定 した。1 次と 2 次のピーク間の谷部での適合は良好であったが， 2 次モードより高振動数領域 $(9 \mathrm{~Hz}$ 以上) での適合が十分ではなく, Case3は $\eta=0.3$, Case 6 は $\eta=0.19$ でそれぞれ収束計算を打ち切った。 式(10)の計測伝達関数と式(19)の理論伝達関数の収束時の形状を各損 傷状態に対し図 13 の右側に示す。収束パラメターは $\eta=0.05$ と設定 した。2 次モードより高振動数領域 $(9 \mathrm{~Hz}$ 以上）での適合が十分で はなく, Case3は $\eta=0.21$, Case6は $\eta=0.09$ で収束計算を打ち切った。 両伝達関数から導かれた物理パラメターの推定值は最終的に一致 した。理論伝達関数の収束時の剛性と減衰の推定值を表 6 に示す。 試験体 Aでは，Case1に対するCase2 とCase3のスウェイばねの変 化を見ると，杭の損傷状態に対応する剛性低下が見られた。とくに 杭頭破断の Case3では急激な剛性低下が見られた。試験体 B におい ても，Case4に対するCase5とCase6のスウェイばねの変化を見る と，損傷状態に対応する剛性低下が観察された。

2 質点系モデルの場合と同様に, 試験体 $\mathrm{A}$ と試験体 B の地盤剛 性のばらつきを調整した後，算出したスウェイばねの剛性低下率を 表 7 に示す。各損傷状態に抢けるスウェイばねの無損傷状態からの 剛性変化を比べると，杭損傷の増大とともに，杭中間部 2 本損傷 $<$ 杭頭 2 本損傷 $<$ 杭中間部 4 本損傷 $<$ 杭頭 4 本損傷 $<$ 杭頭 2 本破断の
表 3 上部構造の同定值

\begin{tabular}{|c|c|c|c|c|}
\hline \multicolumn{2}{|c|}{$\begin{array}{c}\text { 損傷状態 } \\
\text { 剛性 } \mathrm{K}_{\mathrm{b}} \\
(\mathrm{N} / \mathrm{m})\end{array}$} & $\begin{array}{c}\text { 減衰係数 } \mathrm{C}_{\mathrm{b}} \\
(\mathrm{N} \cdot \mathrm{s} / \mathrm{m})\end{array}$ & $\begin{array}{c}\text { 剛性低下率 } \\
(\%)\end{array}$ \\
\hline \multirow{3}{*}{ 試験体A } & Case1 & $6.41 \times 10^{3}$ & $0.39 \times 10[0.015]$ & - \\
\cline { 2 - 5 } & Case2 & $6.41 \times 10^{3}$ & $0.37 \times 10[0.015]$ & 0.0 \\
\cline { 2 - 5 } & Case3 & $6.41 \times 10^{3}$ & $0.34 \times 10[0.013]$ & 0.0 \\
\hline \multirow{4}{*}{ 試験体B } & Case4 & $6.39 \times 10^{3}$ & $0.37 \times 10[0.015]$ & - \\
\cline { 2 - 6 } & Case5 & $6.36 \times 10^{3}$ & $0.37 \times 10[0.015]$ & 0.6 \\
\cline { 2 - 6 } & Case6 & $6.35 \times 10^{3}$ & $0.41 \times 10[0.016]$ & 0.8 \\
\hline
\end{tabular}

[ ]は減衰比

表 4 ロッキングばねの同定值

\begin{tabular}{|c|c|c|c|c|}
\hline \multicolumn{2}{|c|}{$\begin{array}{c}\text { 損傷状態 } \\
\text { 剛性 } \mathrm{K}_{\mathrm{r}} \\
(\mathrm{Nm} / \mathrm{rad})\end{array}$} & $\begin{array}{c}\text { 減衰係数 } \mathrm{C}_{\mathrm{r}} \\
(\mathrm{Nm} \cdot \mathrm{s} / \mathrm{rad})\end{array}$ & $\begin{array}{c}\text { 剛性低下率 } \\
(\%)\end{array}$ \\
\hline \multirow{3}{*}{ 試験体A $\mathrm{A}$} & Case1 & $8.08 \times 10^{3}$ & $3.92 \times 10$ & - \\
\cline { 2 - 5 } & Case2 & $8.08 \times 10^{3}$ & $3.42 \times 10$ & 0.0 \\
\cline { 2 - 5 } & Case3 & $1.16 \times 10^{3}$ & $0.21 \times 10$ & 85.7 \\
\hline \multirow{3}{*}{ 試験体B $\mathrm{B}$} & Case4 & $8.77 \times 10^{3}$ & $0.57 \times 10$ & - \\
\cline { 2 - 5 } & Case5 & $8.77 \times 10^{3}$ & $1.37 \times 10$ & 0.0 \\
\cline { 2 - 5 } & Case6 & $8.77 \times 10^{3}$ & $0.18 \times 10$ & 0.0 \\
\hline
\end{tabular}

表 5 杭 - 地盤系の同定值

\begin{tabular}{|c|c|c|c|c|}
\hline \multicolumn{2}{|c|}{$\begin{array}{c}\text { 損傷状態 } \\
\text { 剛性 } K_{\mathrm{ps}} \\
(\mathrm{N} / \mathrm{m})\end{array}$} & $\begin{array}{c}\text { 減哀係数 } \mathrm{C}_{\mathrm{ps}} \\
(\mathrm{N} \cdot \mathrm{s} / \mathrm{m})\end{array}$ & $\begin{array}{c}\text { 剛性低下率 } \\
(\%)\end{array}$ \\
\hline \multirow{3}{*}{ 試験体A } & Case1 & $7.74 \times 10^{4}$ & $2.55 \times 10^{2}$ & - \\
\cline { 2 - 5 } & Case2 & $7.54 \times 10^{4}$ & $2.25 \times 10^{2}$ & 2.5 \\
\cline { 2 - 5 } & Case3 & $6.46 \times 10^{4}$ & $2.06 \times 10^{2}$ & 16.5 \\
\hline \multirow{4}{*}{ 試験体B $\mathrm{B}$} & Case4 & $8.21 \times 10^{4}$ & $2.69 \times 10^{2}$ & - \\
\cline { 2 - 5 } & Case5 & $8.03 \times 10^{4}$ & $2.60 \times 10^{2}$ & 2.1 \\
\cline { 2 - 5 } & Case6 & $7.39 \times 10^{4}$ & $2.45 \times 10^{2}$ & 9.9 \\
\hline
\end{tabular}

表6 スウェイばねの同定值

\begin{tabular}{|c|c|c|c|c|}
\hline \multicolumn{2}{|c|}{$\begin{array}{c}\text { 損傷状態 } \\
\text { 剛性 } \mathrm{K}_{\mathrm{s}} \\
(\mathrm{N} / \mathrm{m})\end{array}$} & $\begin{array}{c}\text { 減衰係数 } \mathrm{C}_{\mathrm{s}} \\
(\mathrm{N} \cdot \mathrm{s} / \mathrm{m})\end{array}$ & $\begin{array}{c}\text { 剛性低下率 } \\
(\%)\end{array}$ \\
\hline \multirow{3}{*}{ 試験体 $\mathrm{A}$} & Case1 & $7.06 \times 10^{4}$ & $2.25 \times 10^{2}$ & - \\
\cline { 2 - 5 } & Case2 & $6.99 \times 10^{4}$ & $2.01 \times 10^{2}$ & 0.9 \\
\cline { 2 - 5 } & Case3 & $6.17 \times 10^{4}$ & $1.13 \times 10^{2}$ & 12.5 \\
\hline \multirow{3}{*}{ 試験体 $\mathrm{B}$} & Case4 & $7.59 \times 10^{4}$ & $2.35 \times 10^{2}$ & - \\
\cline { 2 - 5 } & Case5 & $7.53 \times 10^{4}$ & $2.45 \times 10^{2}$ & 0.9 \\
\cline { 2 - 5 } & Case6 & $6.96 \times 10^{4}$ & $2.55 \times 10^{2}$ & 8.4 \\
\hline
\end{tabular}

表 7 全体比較のための修正同定值

\begin{tabular}{|c|c|c|c|c|c|c|}
\hline \multirow{3}{*}{ 損傷状態 } & \multicolumn{2}{|c|}{ ロッキングばね } & \multicolumn{2}{|c|}{ 杭一地盤系ばね } & \multicolumn{2}{|c|}{ スウェイばね } \\
\hline & 剛性稆 & 低下率 & 剛性 $K_{p s}$ & 低下率 & 剛性K & 低下率 \\
\hline & $(\mathrm{N} \cdot \mathrm{m} / \mathrm{rad})$ & $(\%)$ & $(\mathrm{N} / \mathrm{m})$ & (\%) & $(\mathrm{N} / \mathrm{m})$ & $(\%)$ \\
\hline Case 1 & 8. $08 \times 10^{3}$ & - & 7. $74 \times 10^{4}$ & - & 7. $06 \times 10^{4}$ & - \\
\hline Case2 & $8.08 \times 10^{3}$ & 0.0 & 7. $54 \times 10^{4}$ & 2. 5 & $6.99 \times 10^{4}$ & 0.9 \\
\hline Case3 & 1. $16 \times 10^{3}$ & 85.7 & 6. $46 \times 10^{4}$ & 16.5 & $6.17 \times 10^{4}$ & 12.5 \\
\hline Case4 & 8. $18 \times 10^{3}$ & 0.4 & 7. $60 \times 10^{4}$ & 1.8 & 7. $03 \times 10^{4}$ & 0.4 \\
\hline Case5 & $8.17 \times 10^{3}$ & 0.4 & 7. $43 \times 10^{4}$ & 3.9 & $6.96 \times 10^{4}$ & 1.3 \\
\hline Case6 & $8.15 \times 10^{3}$ & 0.4 & $6.84 \times 10^{4}$ & 11.5 & $6.44 \times 10^{4}$ & 8.7 \\
\hline
\end{tabular}

順で剛性低下が大きくなる傾向が見られた。2 質点系モデルの結果 と同じになっている。

\section{6 杭頭破断時の挙動}

図12と図13に示したように，杭頭破断のCase3において，他の損 傷状態に比べると理論伝達関数と計測伝達関数の最終形状のずれが 

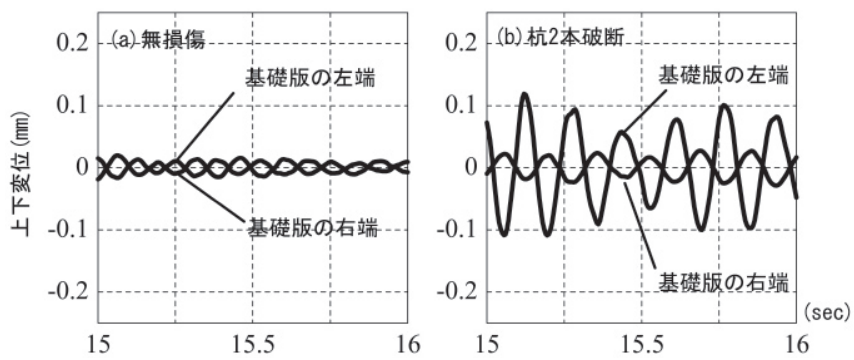

図14 基礎版両端の杭の鉛直変位の時刻歴

大きくなった。この原因として，杭の破断による浮き上がり非線形 性が線形モデルでは再現できなかったことが考えられる。図14に無 損傷状態のCase1と杭頭破断のCase3それぞれに抄ける基礎版の左 端と右端の上下変位の時刻歴波形を示す。Case3では破断杭のある 左端が健全杭のある右端よりも変位がはるかに大きくなっており, 引っ張り側で浮き上がりが生じ，圧縮側でも手で折った際に形成さ れた平滑な破断面ですべりが生じていることがわかる。

\section{9. 結び}

杭を露出することなく, 上部構造と敷地内の杭支持地盤の振動計 測を行うことにより，杭の全体損傷検出を行う多段階システム同定 手法を示し, 模型振動台実験を行って, その有効性と限界を検討し た。本研究の範囲内で得られた知見を以下に要約する。

1. 上部構造の振動波形に含まれる基礎構造の損傷情報を抽出する 上で, 上部構造一杭一地盤連成系の多段階システム同定手法は有 効である。

2. 2 質点系モデルにおける杭 - 地盤系の剛性変化と SR モデルに おけるスウェイばねの剛性変化の同定結果は，実験で設定した杭 の損傷状態に対応しており，ともに杭の全体損傷検出における損 傷指標として有効である。

3. 損傷前後でのロッキングばねの変化は, 実験で設定した杭の損 傷状態に対しては鈍感だったが，破断に対しては敏感だった。杭 と支持地盤の鉛直剛性の比から判断して, この傾向は実建物の場 合でも言えそうである。

4. 理論伝達関数と計測伝達関数の曲線適合の際, 各損傷状態とも 両者の適合は概ね良好だったが，破断すると適合が悪化する傾向 が見られた。これは，破断による浮き上がり非線形性が原因であ り，システム同定に線形モデルを用いた限界と考えられる。

5. 地盤の水平方向の有限性により, 上部構造の振動エネルギーが 表層地盤で十分散逸しない場合でも, 自由地盤表面での入力地震 動と杭一地盤系の等価質量を同定するプロセスを導入することに より，損傷による杭の剛性低下を同定することができる。 なお，本研究では，実験的検証において，簡易な数学モデルを用 い, 入力動は定常振動とし, kinematic interaction を無視するなど, 理想的な条件下で基礎的な検討を行っている。今後, 実建物への適 用に当たって検討すべき課題は少なくない。

\section{謝辞}

本研究の実験は科学研究費補助(c)(2)「振動モニタリングに基づく
建築上部 - 基礎構造の総合的健全性評価に関する研究」(課題番号 14550582）により実施された。実験は2003年10月，(株東急建設技術 研究所の振動台を 1 週間借用して行った。振動台を制御するに当た り, 同研究所豊嶋 豊氏の援助を受けた。

\section{参考文献}

1）地盤工学会：杭基礎の調查・設計・施工から検査まで，地盤工学・実務 シリーズ17, 地盤工学会, 2004

2）濱本卓司，大村哲矢，堀内大吾：振動・波動計測による PHC 杭の総合 的ヘルスモニタリングに関する室内実験, 日本建築学会構造系論文集, No. 612 , pp.47-54, 2007.2

3）濱本卓司，大村哲矢，堀内大吾，崔 井 圭：振動・波動計測に上る場所 打ちコンクリート杭の総合的ヘルスモニタリングに関する室内実験, 日 本建築学会構造系論文集，No. 616，pp.105-112，2007.6

4）川辺一洋, 青木雄二郎, 紫崎富士夫 : 実杭応力の長期計測結果, 日本建 築学会大会学術講演梗概集, B, pp.1171-1172, 1986.7

5）加藤洋一, 田村昌仁, 勅使川原正臣, 坂田光児：光ファイバーを利用し た杭の損傷検知センサの開発（その $1 \sim 3$ ), 日本建築学会大会学術講演 梗概集，B-2，pp.7-10，2005.7；B-2，pp.861-862，2006.7

6）稲田 裕, 石井 清, 杉村義広, 佐々木建一：炭素繊維束センサの杭の 損傷検知に対する性能評価（杭の健全性モニタリング手法の開発（その 2)）， 日本建築学会構造系論文集，No.495，pp.63-70，1997.5

7）大場新太郎, 濱川尚子：1995年兵庫県南部地震における杭の損傷による 建物固有周期の変化，日本建築学会構造系論文集，No.495, pp.63-70, 1997.5

8) Luco, J.E., Trifunac, M.D., Wong, H.L.: Isolation of Soil-Structure Interaction Effects by Full-scale Forced Vibration Tests, Earthquake Engineering and Structural Dynamics, Vol. 16, pp.1-21, 1988

9) Trifunac, M.D., Ivanovic, S.S., Todorovska, M.I. : Apparent Periods of a Building. I : Fourier Analysis, Journal of Structural Engineering, Vol. 127, No. 5, ASCE, pp.517-526, 2001

10) Trifunac, M.D., Ivanovic, S.S., Todorovska, M.I. : Apparent Periods of a Building. II : Time-Frequency Analysis, Journal of Structural Engineering, Vol. 127, No. 5, ASCE, pp.527-537, 2001

11) Safak E. : Detection and Identification of Soil-Structure Interaction in Buildings from Vibration Recordings, Journal of Structural Engineering, Vol. 121, No. 5, ASCE, pp.899-906, 1995

12) Stewart, J.P., Fenves, G.L. : System Identification for Evaluating SoilStructure Interaction Effects in Buildings from Strong Motion Records, Earthquake Engineering and Structural Dynamics, Vol. 27, pp.869-885, 1998

13) Stewart, J.P., Fenves, G.L., Seed, R.B. : Seismic Soil-Structure Interaction in Buildings. I: Analytical Methods, Journal of Geotechnical and Geoenvironmental Engineering, Vol. 125, No. 1, ASCE, pp.26-37, 1999

14) Stewart, J.P., Fenves, G.L., Seed, R.B. : Seismic Soil-Structure Interaction in Buildings. II : Empirical Findings, Journal of Geotechnical and Geoenvironmental Engineering, Vol. 125, No. 1, ASCE, pp.38-48, 1999

15）原口 圭, 神田 順, 稲垣光剛：常時微動測定による中低層建物を対象 とした地盤・建物相互作用系の同定手法, 日本建築学会構造系論文集, No. 564, pp.31-37, 2003.2

16）柴田明德：最新耐震構造解析，森北出版，1981

17) Timoshenko S., Young D. H., and Weaver Jr. W.: Vibration Problems in Engineering, John Wiley and Sons, New York, 1974

18）長松昭男：モード解析入門，コロナ社, 1993

19）市田浩三，吉本富士市：スプライン関数とその応用，教育出版，1979

20）坂和正敏：非線形システム最適化, 森北出版, 1986

21）日本建築学会：入門 - 建物と地盤との動的相互作用, 日本建築学会, 1996

22）日本建築学会：建物と地盤の動的相互作用を考慮した応答解析と耐震設 計, 日本建築学会, 2004

（2010年 1 月 8 日原稿受理，2010年 5 月13日採用決定） 